\title{
PERSPECTIVES OF SOCIAL ASPECTS OF SUSTAINABLE DEVELOPMENT IN THE LATVIA'S REGION LATGALE
}

\author{
Valērijs Makarevičs
}

Daugavpils University, Latvia

\begin{abstract}
For the conception of sustainable development the elaboration of indicators allowing to determine its tendencies is of major importance. The practice shows that the lists of sustainable development criteria suggested at present do not take into consideration the pecularities of particular regions. Modern theories of sustainable development consider this phenomenon in three aspects: economic, ecological and social. The article considers the tendencies of sustainable development in the social sphere in Latgale in comparison to other regions of Latvia. The indicator here is the condition and possibilities of development of human capital (decent life for generations). The method of the research is the analysis of the statistical data. The conclusion is made on the basis of the research that the situation in the social sphere of Latgale does not correspond to the requirements of sustainable development. Research has two aims: to check the criteria of sustainbility development often mentioned in scientific literature in relation to Latvia; research of social aspect of sustainable development of east region of Latvia.
\end{abstract}

Keywords: Demography, education, human capital, Latgale, sustainable development.

\section{Introduction}

Thirty years have passed since the time when the World Commission on Environment and Development - WCDE was founded by the General Assembly of the UNO. Its first head was the prime minister of Norway Gro Harlem Brundtland. The Commission had to develop the main principles and indicators of sustainable development as well as the programme of actions to implement the ideas of sustainable development into life. In 1987 the first results of the work of the commission appeared. They are reflected in the report „Our common future". In this report a new conception of sustainable development as an alternative to the extensive unlimited economic growth was represented as well as the notion of the phenomenon most widely used up to now.

The authors understand sustainable development as the development under which the present generations satisfy their needs and, at that, do not 
Valērijs Makarevičs. Perspectives of Social Aspects of Sustainable Development in the Latvia's Region Latgale

threaten the possibility for the future generations to satisfy their needs (Bruntsland et al., 1987).

A lot of documents, theories, researches and books dedicated to this problem have appeared (Bossel, 1999; Brown \& Kane, 1994; Colartonio, 2007; Meadows, 1995; Mori \& Christodoulou, 2012; Murai, 1995a; Hardi, Barg, Hodge, Pinter et al., 1997) in these 30 years. The main themes are determining the criteria of sustainable development, stating on the basis of these criteria. The situation with sustainable development for a concrete region should be taken into account. Research has two aims: to check the criteria of sustainability development often mentioned in scientific literature in relation to Latvia; research of social aspect of sustainable development of east region of Latvia. The method of analysis of statistical information is applied.

\section{Criteria and indicators of sustainable development}

Elaborating the criteria of sustainable development is one of the main, and at the same time difficult to solve, tasks of this sphere of a person's activity. In the 90s the variant suggested by Meandows and Murai gained popularity. It was distinguished for being compact and contained only 8 indicators.

Table 1 Indicators of sustainable development according to Meandows and Murai (Meandows, 1995; Murai, 1995a)

\begin{tabular}{|l|c|c|c|}
\hline $\begin{array}{l}\text { Indicator of sustainable } \\
\text { development }\end{array}$ & Sustainable & Critical & Destructive \\
\hline $\begin{array}{l}\text { Growth of population \% per } \\
\text { year }\end{array}$ & $<0.5 \%$ per year & $1.0 \%-1.5 \%$ & $>2.0 \%$ \\
\hline $\begin{array}{l}\text { Gross national product per } \\
\text { year,\% }\end{array}$ & $3 \%<$ GNP<5\% & $8 \%<G N P<10 \%$ & $\begin{array}{l}G N P>10 \% \\
G N P<0 \%\end{array}$ \\
\hline $\begin{array}{l}\text { Relative area of forests \% } \\
\text { Deforesting, \% per year }\end{array}$ & $<0,1 \%$ per year & $0.5 \%-1.0 \%$ & $>1 \%$ \\
\hline Relative area of forests \% & $>30 \%$ & $15 \%-20 \%$ & $<10 \%$ \\
\hline $\begin{array}{l}\text { Area of ploughed field } \\
\text { ha/person }\end{array}$ & $>0 / 3$ & $0.15-0.2$ & $<0.1$ \\
\hline Provision with own grain \% & $>90 \%$ & $60 \%-70 \%$ & $<50 \%$ \\
\hline $\begin{array}{l}\text { Density of urban population, } \\
\text { person/ha }\end{array}$ & $<50$ & $100-150$ & $>200$ \\
\hline $\begin{array}{l}\text { Amount of urban } \\
\text { population, mln }\end{array}$ & $<0.5$ & $>1$ & $>10 m \ln ? ? ?$ \\
\hline
\end{tabular}

Having analysed the situation in the separate regions of the planet, the authors summarised the results and came to the conclusion that sustainability or nonsustainability of development on the global level (on each of the continents 
of the Earth) can be determined with the help of the eight indicators mentioned above. However, the authors themselves note down the main drawback of the conception: nonscientific approach when the indicators were determined on the basis of life experience. Nevertheless, as Murai notes, the results received using this approach reflect the real tendencies of development on the global (continental) level (Murai, 1995b). Later Meandows and Murai's approach of researching the tendencies of sustainable development began to be used not only on the global but also on the regional level (Gurler, Erdal, \& Erdal, 2006; Kizilaslan, 2007).

Elaborating the criteria of sustainable development is going on. Both international organisations and individual authors suggest their approaches. These new conceptions include three directions: the quantitative increase of the number of indeces, concentration of attention on the separate aspects of sustainable development and attempts of the systemic solution of the problem. As an example, the indicators of sustainable development suggested by the UNO Commission can be mentioned. With their help all three sides of the phenomenon can be evaluated. It is interesting to note that the initial list was reduced to 132 points. The reason is that with a big number of indicators there appear difficulties in the organization of the research (Indicators of Sustainable Development, 1994).

Within the framework of OECD there is a discussion about the ways for measuring the human and social capital as the most important constituent of the social side of sustainable development (OECD, 1998, 2001).

The attempts to use the systemic approach to elaborating the indicators of sustainable development will be referred to the third group of conceptions. Here Bossel's conception of the indicators of sustainable development should be mentioned. He considers the interaction of the system and the elements below the system as the basis of development (Bossel, 1999).

\section{Advantages and disadvantages of Meandows and Murai's conception (on the example of Latvia)}

As we have already noted, at present there is no ideal system of indicators of sustainable development which could be used in any place of the planet. The researchers point down that elaborating such a system is an extremely expensive procedure requiring a big amount of information which can be difficult or sometimes even impossible to receive (Tarasova \& Kruchina, 2006).

To reveal the advantages and disadvantages of this point of view let us analyse the situation in Latvia. To receive an idea about the situation in dynamics let us consider the situation in Latvia in 2000 and 2010. We will turn to Tables 2 and 3. The year 2000 is a year of economic growth when the country 
Valērijs Makarevičs. Perspectives of Social Aspects of Sustainable Development in the Latvia's Region Latgale

was preparing to enter the EU. 2010 is the year of economic decline after the crisis. Let us note as well that the indicators of density of urban population and the amount of urban population do not refer, like the other indicators, to the whole country, but to a concrete place. In our pilot research we put together the area and amount of population of 5 biggest cities of Latvia: Riga, Daugavpils, Jelgava, Liepaja, Ventspils, Rezekne and found the indicators common to these cities.

The results of our research show that, according to the formal indicators, in 2000 and 2010 Latvia corresponded to the criteria of sustainable development (according to Meandows and Murai's model), as only two out of eight criteria (gross national product and provision with own grain) appeared in different graphs not corresponding sustainability in development. However, a deeper analysis of socioeconomic processes taking place in Latvia shows a different picture.

Table 2 Indicators of sustainable development (according to Meandows and Murai) in Latvia in 2000

\begin{tabular}{|l|c|c|c|}
\hline $\begin{array}{l}\text { Indicator of sustainable } \\
\text { development }\end{array}$ & Sustainable & Critical & Destructive \\
\hline Growth of population \% per year & $-0,73$ & & \\
\hline $\begin{array}{l}\text { Gross national product per } \\
\text { year,\% }\end{array}$ & $45.1 \%$ & & \\
\hline Relative area of forests \% & $\begin{array}{l}\text { Increase in the } \\
\text { forest area 0.3 }\end{array}$ & & \\
\hline Deforesting, \% per year & 0.41 & 89 & \\
\hline Area of ploughed field ha/person & 20 & & \\
\hline Provision with own grain \% & & & \\
\hline $\begin{array}{l}\text { Density of urban population, } \\
\text { person/ha }\end{array}$ & $\begin{array}{l}\text { Average amount } \\
\text { of population in } \\
\text { a big city } 185 \\
453\end{array}$ & & \\
\hline $\begin{array}{l}\text { Amount of urban population, } \\
\text { mln }\end{array}$ & & & \\
\hline
\end{tabular}

Let us take the first criterion. According to Meandows and Murai's point of view, the decrease of the number of inhabitants living in a certain region is a positive indicator of sustainable development. For overpopulated, first of all Asian regions of the world, this statement is true. For Latvia, this indicator is connected first of all with emigration processes. People of working age are leaving. The main reasons for this are lack of vacancies and low salaries which do not provide for decent living standards. Leaving the country, the emigrants (they are also called labour migrants) increase the number of the inhabitants of 
the receiving country, thus preserving the overall balance of the world population. They pay taxes and make purchases, supporting the economy not of their own country, but of the receiving country. Thus, this criterion does not take into account reasons for the changes in the population amount, as well as the fact that there exists an optimal amount of inhabitants for every region which is needed for providing the economic activity in this territory and at that, does not effect negatively the ecosystems.

Table 3 Indicators of sustainable development (according to Meandows and Murai) in Latvia in 2010

\begin{tabular}{|c|c|c|c|}
\hline $\begin{array}{l}\text { Indicator of sustainable } \\
\text { development }\end{array}$ & Sustainable & Critical & Destructive \\
\hline Growth of population $\%$ per year & -0.83 & & \\
\hline $\begin{array}{l}\text { Gross national product per } \\
\text { year, } \%\end{array}$ & & & -0.5 \\
\hline Relative area of forests \% & 50.3 & & \\
\hline Deforesting, $\%$ per year & 0 & & \\
\hline Area of ploughed field ha/person & 0.52 & & \\
\hline Provision with own grain $\%$ & & 59.2 & \\
\hline $\begin{array}{l}\text { Density of urban population, } \\
\text { person/ha }\end{array}$ & 18 & & \\
\hline $\begin{array}{l}\text { Amount of urban population, } \\
\mathrm{mln}\end{array}$ & $\begin{array}{l}\text { Average amount } \\
\text { of population in } \\
\text { a big city } \\
171218\end{array}$ & & \\
\hline
\end{tabular}

Now let us touch upon the problem of provision with grain. According to the authors, provision with the grain of own production is one of the main indicators of sustainable development of the region. But here the effect of the market laws (when the balance of prices affects the export and/or import of grain) is not taken into account.

Let us draw the conclusions. First of all, it does not take into consideration the regional conditions. Secondly, it does not include the interrelation of the indicators. Its hierarchical model in which the interrelations between the indicators would be shown (the decrease of the gross national product - the increase of the number of labour migrants; not only the fixation of the crop grown in the region, but the correlation of grain export and import as well, etc.). Thirdly, the emphasis here is placed upon the ecological conditions of sustainable development and therefore the number of indicators needs to be added and expanded including the humanitarian criteria.

Commentary: the data used in Tables 2 and 3 were taken from the sources indicated below. 
Valērijs Makarevičs. Perspectives of Social Aspects of Sustainable Development in the Latvia's Region Latgale

The data for such indicators as growth of population, deforesting, relative area of forests, the area of ploughed field were taken from Centrālās statistikas pārvaldes datu bazes. The data on gross national product were taken from the article „Latvijas ceḷš uz nekurieni”, placed on the Internet site Tautsaimniecības blogs. The statistical data on the provision with own grain were taken from the source: Lauksaimniecības nozaru attīitības tendences un prognozes. 2010. gada 5. martā

\section{The demographic situation in Latgale}

In this part of the article we will pay attention to the problems of social sustainable development in the Latgale region. Out of all the spectrum of indicators suggested by the science we will choose the following: the demographic situation in the region, the educational policy and providing the well-being of the inhabitants of the region, The method of the research: the analysis of statistical data of the demographic situation in Latgale presented in different sources.

The main task of the sustainable development of society is to provide decent life for the present and following generations. This task is solved in different ways on the global and local (regional) levels. The global level of solving this task envisages the measures on decreasing the tempo of the planet's population growth (alongside with other economic, ecological and political measures). On the local or regional level the solution may be exactly the opposite: whether in some territories any inhabitants will stay for whom the tasks and aims of sustainable development of territories and regions will be topical.

Let us turn to the demographic situation in Latgale's planning region and compare it with the situation in other regions paying attention to the dynamics of changes starting from 2000 and finishing with 2012. The data are presented in Table 4.

Table 4 Number of inhabitants in regions of Latvia in different years

\begin{tabular}{|l|c|c|c|c|}
\hline Regions/Years & 2000 & 2004 & 2008 & 2012 \\
\hline Riga and Riga's region & 1124480 & 1084950 & 1070012 & 1018657 \\
\hline Vidzeme & 256087 & 243342 & 228424 & 208129 \\
\hline Kurzeme & 322221 & 305926 & 290637 & 266313 \\
\hline Zemgale & 293267 & 282421 & 271123 & 250177 \\
\hline Latgale & 385660 & 359881 & 331614 & 298487 \\
\hline
\end{tabular}

(Sourse: Centrālās statistikas pārvaldes datu bazes. http://data.csb.gov.lv/). 
The table shows that the number of population in all regions decreased. Let us compare these losses in each region of the country. Years 2000 and 2012 have been chosen for comparison.

Table 5 Comparative data $(\%)$ on the changes of population number in regions and their fraction in the total population of the country

\begin{tabular}{|l|c|c|c|}
\hline $\begin{array}{l}\text { Regions/Number } \\
\text { of inhabitants (\%) }\end{array}$ & $\begin{array}{c}\text { \% of region's } \\
\text { population in 2012 } \\
\text { as compared to 2000 }\end{array}$ & $\begin{array}{c}\text { \% of region's } \\
\text { population as } \\
\text { compared to } \\
\text { republic's population } \\
\text { (2000) }\end{array}$ & $\begin{array}{c}\text { \% of region's } \\
\text { population as } \\
\text { compared to } \\
\text { republic's population } \\
\text { (2012) }\end{array}$ \\
\hline $\begin{array}{l}\text { Riga and Riga's } \\
\text { region }\end{array}$ & 90.6 & 47.2 & 49.9 \\
\hline Vidzeme & 81.3 & 10.8 & 10.2 \\
\hline Kurzeme & 82.6 & 13.5 & 13.0 \\
\hline Zemgale & 85.3 & 12.3 & 12.3 \\
\hline Laigale & 77.4 & 16.2 & 14.6 \\
\hline
\end{tabular}

(Sourse: Centrālās statistikas pārvaldes datu bazes. http://data.csb.gov.lv/ ).

It is seen from Tables 4 and 5 that Vidzeme and Latgale lose their inhabitants most rapidly.At that, a town egualling Kraslava in size disappears in Latgale every 6 months.

Riga, Riga's region and Zemgale are most favourable from the point of view of the demographic situation.

For the sustainable development it is needed that $15000-20000$ people live on the territory of an administrative unit (in Latvia they are small regions (novads-in Latvian) and municipalities of the republican subordination.

According to the calculations of the Russian scientists Frolov and Agafonova, it is necessary that $65 \%$ (of the whole number) of population able to work at the $95 \%$ level of employment live in the administrative territory (Frolov \& Agafonova, 2011).

This is an optimal number of inhabitants which allows to develop the social infrastructure: to keep schools (there are pupils), to open shops (there are customers), to organize public transport traffic (there are passengers), to provide social support to those in need (there are tax payers and the percentage of unemployed does not exceed 5-10\%).

Let us consider the situation in Latgale as to the number of inhabitants for one administrative unit (small region) and compare it with the situation in other regions of Latvia. 
Valērijs Makarevičs. Perspectives of Social Aspects of Sustainable Development in the Latvia's Region Latgale

Table 6 Population density and the average number of inhabitants on the territory of a district or municipality in the regions of Latvia

\begin{tabular}{|c|c|c|c|c|}
\hline $\begin{array}{c}\text { Regions/Data } \\
\text { on inhabitants }\end{array}$ & $\begin{array}{c}\text { Population } \\
\text { density } \\
\text { people/km2 } \\
(2000)\end{array}$ & $\begin{array}{c}\text { Average number } \\
\text { of inhabitants of } \\
\text { the small } \\
\text { regions }\end{array}$ & $\begin{array}{c}\text { Population } \\
\text { density } \\
\text { people/km2 } \\
(2012)\end{array}$ & $\begin{array}{c}\text { Average number } \\
\text { of inhabitants of } \\
\text { the small region }\end{array}$ \\
\hline $\begin{array}{c}\text { Riga and } \\
\text { Riga's region }\end{array}$ & 114 & 37482.7 & 103.2 & 33955.2 \\
\hline Vidzeme & 19.1 & 9484.6 & 15.6 & 7708.5 \\
\hline Kurzeme & 21.8 & 16111.9 & 18.0 & 13315.7 \\
\hline Zemgale & 27.3 & 13330.3 & 23.3 & 11371.3 \\
\hline Latgale & 23.5 & 16767.8 & 18.2 & 12977.7 \\
\hline
\end{tabular}

(Sourse: Centrālās statistikas pārvaldes datu bazes http://data.csb.gov.lv/ ).

While calculating the population density the following data as to the region of planning were used: Riga and Riga's region - $9870.2 \mathrm{~km} 2$; Vidzeme $13381.5 \mathrm{~km} 2$; Kurzeme - $14771.7 \mathrm{~km} 2$; Zemgale - 10738.8 km2; Latgale $16424.3 \mathrm{~km} 2$.

Two artificial suppositions were used in the table. The first one is that the new administrative division into small regions (novadi) and city municipalities was implemented in Latvia in 2009. In 2000 the structure of administrative division was different. We changed the structure intentionally to compare the data of 2012 with those of 2000.

According to the Minister Cabinet Decision Nr. 381 about the territories of planning regions, Riga's region consists of 2 city municipalities and 28 small regions; Vidzemes region - of one city municipality and 26 small regions. Correspondingly in Kurzeme 2+18, Zemgale $-2+20$, Latgale $-2+21$ (Latvijas Republikas tiesību akti, 2011).

The second supposition is connected with the fact that in the research we use the average data of the number of inhabitants in a small region (total number of inhabitants of the region divided by the number of city municipalities and small regions (novadi) in the region). This supposition is made as we are interested in the region on the whole,but not in a concrete city or small region.

As to the average number of inhabitants for one administrative unit of the region, here Riga and Riga's region are leading. The situation is obvious: the centre of the region is the largest city in Latvia. At that, people can come to work to Riga practically from every place in Riga's region.

The situation in Latgale in 2000 was stable. In 2012 in spite of the presence of two cities of the republican subordination, it becomes unstable. The inhabitants of the region have already experienced this unstability: bus routes which used to be popular are being closed, the schools are liquidated (by the 
way, the only school which is planned to be closed down in 2013 is located in Latgale), the prices in the shops go up due to the decrease of the number of customers and, consequently, of the trade turnover.

According to this indicator the most critical situation is in Vidzeme. According to many other indicators which we have already discussed and will still discuss in this article, Vidzeme is close to Latgale. Latgale is often called a depressive region. Maybe, it is not the only one in Latvia?

Undoubtedly, the sustainable development of the society in Latvia and Latgale is connected with the increase of the birthrate. In this does not happen, not more than 100000 will live in Latgale in 2050 (equalling the population of such city as Daugavpils in the middle of 2000).

Children are born predominantly in families. Therefore, we will have a look at the dynamics of the number of marriages in different regions of Latvia. To compare the results let us pay attention to the relative indicator: the number of marriages per 1000 people in a region. The years 2000, 2004, 2008 and 2011 have been taken for comparison (no statistical data for 2012 yet).

In 2011 there was the population census (the last one). We use its data to determine the number of concluded marriages per 1000 people in a region. The data were as follows: Riga and Riga's region - 1028459; Vidzeme - 211233; Kurzeme -270168; Zemgale - 254238; Latgale - 303789 (Iedzīvotāju skaits, 2011: 6).

Table 7 Absolute and relative number of concluded marriages according to the regions of Latvia from 2000 to 2011

\begin{tabular}{|l|l|l|l|l|l|l|l|l|}
\hline $\begin{array}{l}\text { Regions/ } \\
\text { Indicators }\end{array}$ & $\begin{array}{l}\text { Conclu- } \\
\text { ded } \\
\text { marriages } \\
(2000)\end{array}$ & $\begin{array}{l}\text { Number } \\
\text { of } \\
\text { marriages } \\
\text { per 1000 } \\
(2000)\end{array}$ & $\begin{array}{l}\text { Conclu- } \\
\text { ded } \\
\text { marri- } \\
\text { ages } \\
(2004)\end{array}$ & $\begin{array}{l}\text { Number } \\
\text { of } \\
\text { marriages } \\
\text { per 1000 } \\
(2004)\end{array}$ & $\begin{array}{l}\text { Conclu- } \\
\text { ded } \\
\text { marri- } \\
\text { ages } \\
(2008)\end{array}$ & $\begin{array}{l}\text { Number } \\
\text { of } \\
\text { marriages } \\
\text { per 1000 } \\
(2008)\end{array}$ & $\begin{array}{l}\text { Conclu- } \\
\text { ded } \\
\text { marri- } \\
\text { ages } \\
(2011)\end{array}$ & $\begin{array}{l}\text { Number } \\
\text { of } \\
\text { marriages } \\
\text { per 1000 } \\
(2012)\end{array}$ \\
\hline $\begin{array}{l}\text { Riga and } \\
\text { Riga's } \\
\text { region }\end{array}$ & 4965 & 4,4 & 5555 & 5.1 & 6702 & 6,7 & 5550 & 5.4 \\
\hline Vidzeme & 765 & 3.0 & 814 & 3.3 & 1166 & 5.1 & 899 & 4.3 \\
\hline Kurzeme & 1140 & 3.5 & 1319 & 4.3 & 1621 & 5.6 & 1340 & 5.0 \\
\hline Zemgale & 951 & 3.2 & 1195 & 4.2 & 1561 & 5.6 & 1304 & 5.1 \\
\hline Latgale & 1390 & 3.6 & 1487 & 4.1 & 1889 & 5.7 & 1657 & 5.5 \\
\hline
\end{tabular}

(Sourse: Centrālās statistikas pārvaldes datu bazes http://data.csb.gov.lv/).

It is seen from the table that Latgale occupies the leading position as to the number of concluded marriages per 1000 (except 2004). In 2011 Latgale is an absolute leader in the number of concluded marriages per 1000 people. These data give hope for the improvement of the demographic situation in the region. 
Valērijs Makarevičs. Perspectives of Social Aspects of Sustainable Development in the Latvia's Region Latgale

At the same time we will note that, according to this indicator, the worst results, both absolute and relative, were received in Vidzeme region.

\section{Human capital - the basis of sustainable development of the region}

Human capital is a notion which has recently entered the lexicon of politicians, economists and sociologists (Barro, 1998; Becker, 1993; OECD, 1998; Shultz et al., 1972). Human capital presupposes the presence of a sufficient number of educated and professionally trained people who can satisfy their everyday needs and support their families for the salary for fulfilled work. All the other forms of capital are secondary as they acquire their value in the result of human activity (Slaus \& Jacobs, 2011).

We have considered the problem of preserving the human capital on the territory of Latgale.

Now let us turn to the problem of human capital development, and namely, to the problem of education and reward for labour.

Education starts from school. For primary school pupils it is very important that the school is located close to their home. But the decreasing number of the inhabitants of the region and of schoolchildren does not facilitate the increase of the number of schools. Moreover, the number of schools becomes smaller and smaller with every year.

Let us turn to figure 1.

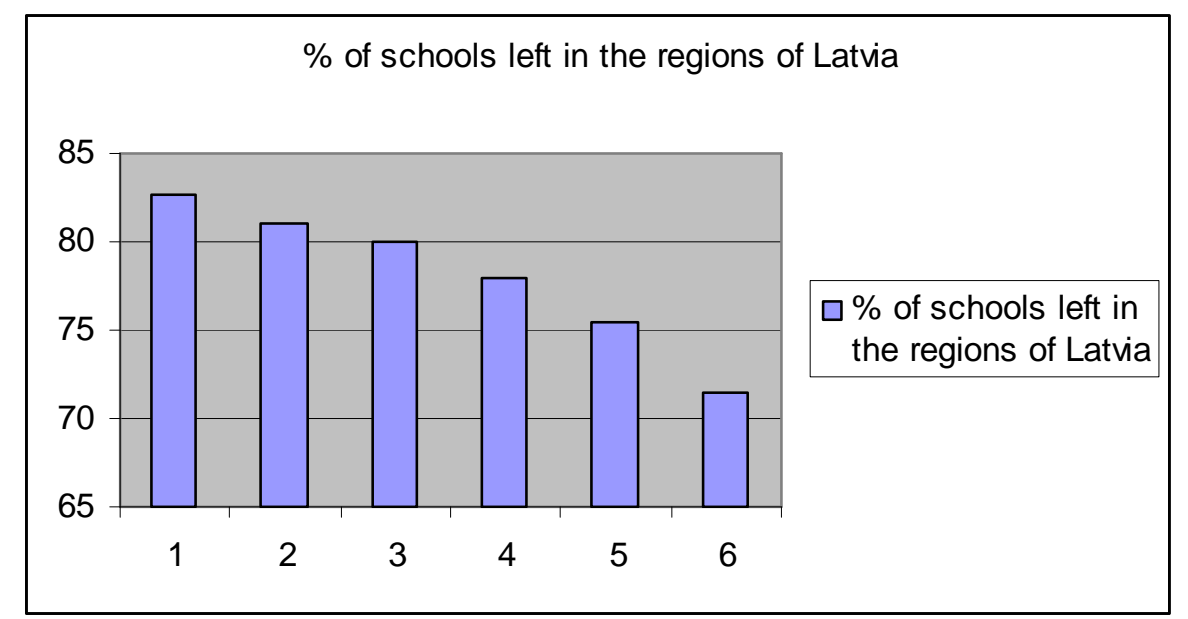

Fig.1 The percentage of schools left in the regions of Latvia from 2000 till 2012. 2000 - $100 \%$.

(Sourse: Centrālās statistikas pārvaldes datu bazes. http://data.csb.gov.lv/).

Figure 1 shows the situation with the number of Latvian schools preserved since 2000. The numbers of columns and their size correspond to: Riga and 
Riga's regions $-82,6 \%$; Vidzeme $-81 \%$; Kurzeme $-80 \%$; Latvia on the whole - $78 \%$; Zemgale - 75,4\%; Latgale - 71,5\%.

For the past 12 years every fourth school was closed down in Latgale.

This is connected to the decreasing number of pupils. Let us turn to Figure 2.

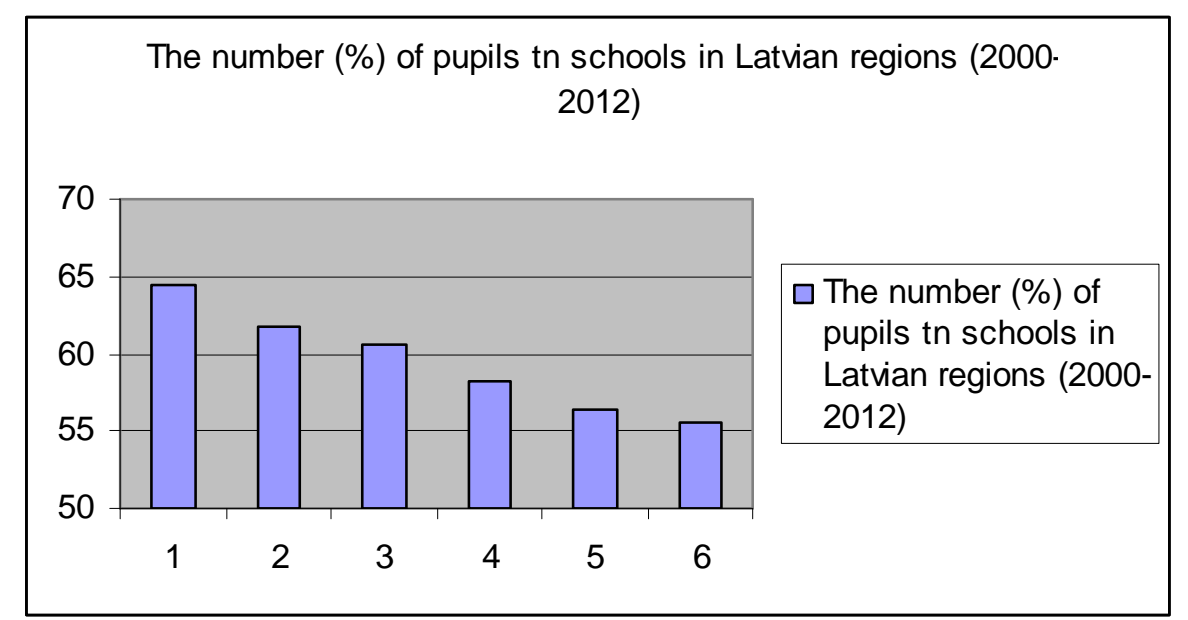

Fig.2 The number (\%) of pupils of general education schools in Latvian regions in 2012 as compared to $\mathbf{2 0 0 0 .}$

(Sourse: Centrālās statistikas pārvaldes datu bazes. http://data.csb.gov.lv/ )

Let us decipher the data. 1. Riga and Riga's region $-64,5 \% ; 2$. Latvia on the whole $-61,7 \%$; 3 . Kurzeme - 60,6 \%; Zemgale - 58,3\%; Latgale - 56,45 $\%$; Vidzeme $-55,5 \%$.

While comparing fig. 1 and 2 a question arises: Vidzeme has lost during these years most of the pupils but preserved the number of schools. Which reasons were underlying the fact that Latgale lost such a number of schools but a smaller number of pupils during these years?

The number of pupils in school forms is the dynamic category which changes with every year. They are replaced by those who today attend preschool educational establishments or are brought up at home. Let us turn to the statistical data about the children who attend the preschool establishments (there are no statistical data about the children who are brought up in families and do not attend preschool establishment in separate regions).

In fig.3: 1 is Riga and Riga's region - increase 164,6 \%; 2- Zemgale $157,1 \% ; 3$ - Latvia on the whole - 151,5\%; 4 - Latgale - 136,1 \%; 5 Kurzeme - 135,5\%; 6 - Vidzeme - 127,5\%.

At first sight, everything looks like Latgale is lagging behind Zemgale and Riga's region in this indicator, but comes before Kurzeme and Vidzeme. But everything changes when we take a different, shorter period of tine, from 2005 (the peak of the so called „fat" years) till 2012. 
Valērijs Makarevičs. Perspectives of Social Aspects of Sustainable Development in the Latvia's Region Latgale

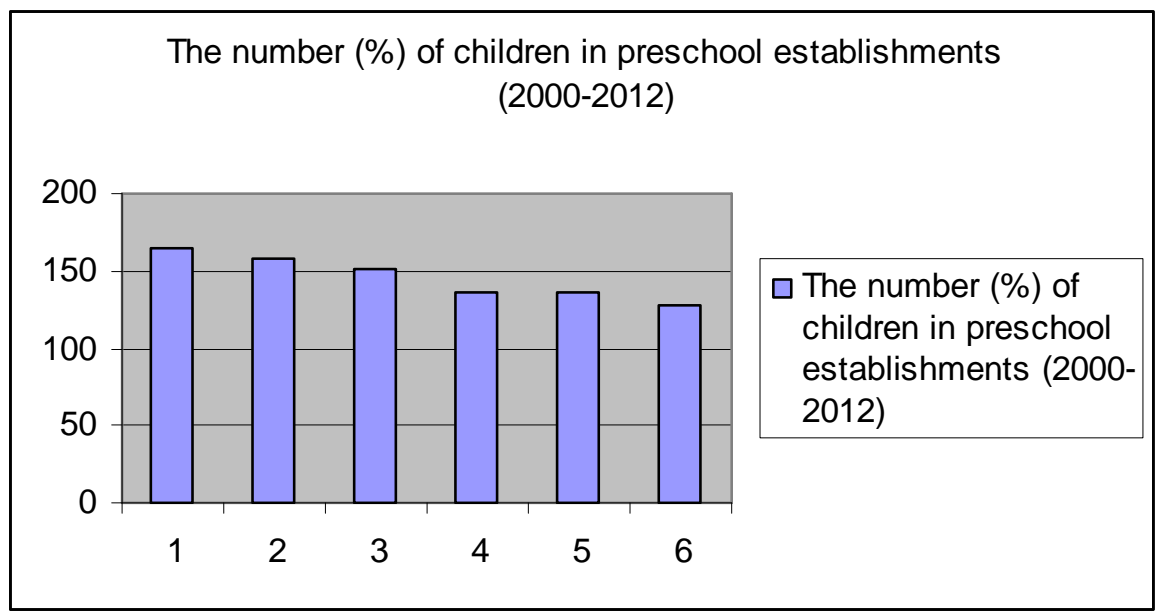

Fig. 3 The number of children in preschool establishments in regions of Latvia (2012 as compared to 2000 , in \%).

(Sourse: Centrālās statistikas pārvaldes datu bazes. http://data.csb.gov.lv/ )

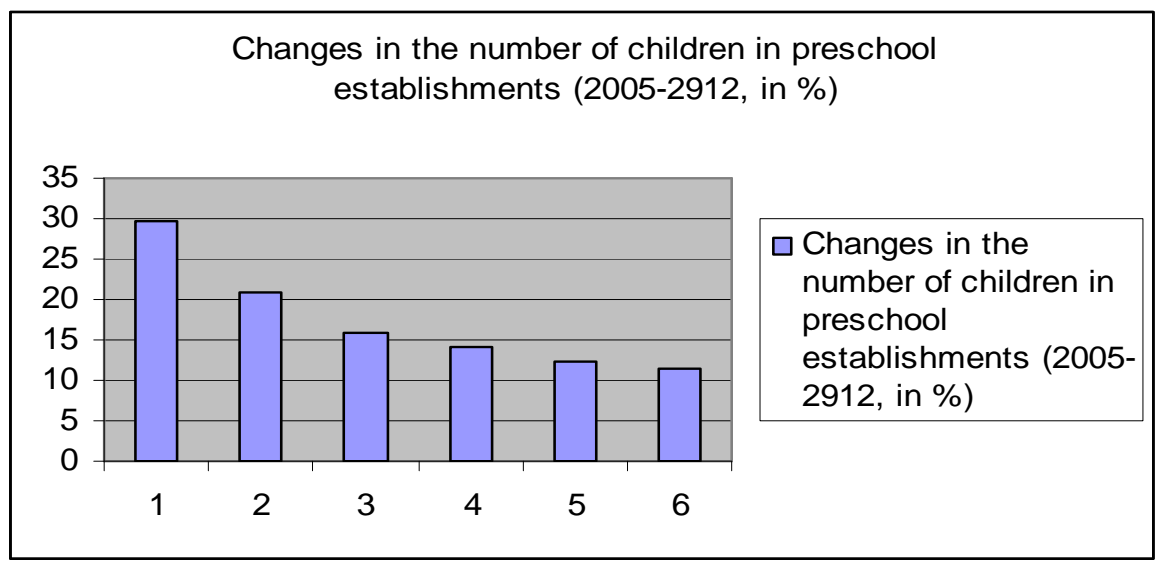

Fig.4 Changes in the number of children in preschool establishments in regions of Latvia in 2012 as compared to 2005 , in $\%$.

(Sourse: Centrālās statistikas pārvaldes datu bazes. http://data.csb.gov.lv/ )

In Figure 4 the figures 1-6 mean the following: 1 -Riga and Riga's region increase $29,7 \% ; 2$ - Latvia on the whole $-21 \% ; 3$ - Zemgale - $16 \% ; 4$ Kurzeme - $14 \% ; 5$ - Latgale - 12,4\%; 6 - Vidzeme - 11,4\%.

The figures tell us that in the coming 4-5 years much more first graders will come to schools than in the previous years. This inflow will be experienced, first of all, by the schools of Riga's region. New forms will have to be opened and new primary schools teachers will be needed.

But this need in new forms and teachers has a fluctuating nature. The demographic tendencies show that in 2-3 years there will be another decrease of the birthrate. At that time those who came to school in the preceding 4 years will already study in the basic school (which, in its turn, will demand the increase of 
the number of basic school teachers and the decrease of the primary school teachers).

This problem will touch upon Latgale's schools to a smaller degree. Latgale's schools can take an additional number of pupils in the limits which are shown by the figures of the increase of preschool children number indicated above.

We should also note the discrepancy between the number of marriages per 1000 people (Latgale is leading here) and the number of preschool children (Latgale is at the end of the list). This testifies to the fact that young families leave Latgale. The children appear in these families in other places, not in Latgale.

The reason of their departure is obvious: low salaries. Let as turn to table 8 .

Table 8 Brutto salaries (average, in Ls) in different regions of Latvia before the crisis and in post crisis 2012

\begin{tabular}{|c|c|c|c|}
\hline Regions/Brutto salaries in Ls & 2008 & 2012 & Difference \\
\hline Riga and Riga's region & 527 & 528 & +1 \\
\hline Vidzeme & 381 & 371 & -10 \\
\hline Kurzeme & 408 & 420 & +12 \\
\hline Zemgale & 345 & 402 & +57 \\
\hline Latgale & 341 & 334 & -7 \\
\hline
\end{tabular}

(Sourse: Centrālās statistikas pārvaldes datu bazes. http://data.csb.gov.lv/)

Riga and Riga's region are absolute leaders here. As to the tempo of increase of the average brutto salary, it is Zemgale (thanks to Jelgava wich is attractive for foreign investors).

Latgale, as well as Vidzeme, occupy the last places in this list.

What does the average brutto salary of 334 Ls mean for a family in Latgale? Let us suppose that a family consists of 4 people: parents and two children of school age. According to statistics, one of the parents is unemployed. Children's allowance is 16 Ls. If we divide the family income upon the number of family members (87,5 Ls per person per month), it will turn out that a prisoner has a bigger sum of money for living and, at that, does not pay any taxes (316, 20 Ls per person) (Ieslodzījuma vietu pārvaldes publiskais pārskats, 2012). 
Valērijs Makarevičs. Perspectives of Social Aspects of Sustainable Development in the Latvia's Region Latgale

\section{Conclusion}

1. The criteria of sustainable development considered in the article do not take into account all features of region.

2. The basic problems of sustainable development of Latgale in social sphere are reduction of number of habitants and low profits.

3. The indicated problems reduce efficiency of actions of municipal authorities in a social sphere.

4. In the sphere of education these problems shows up in closing of schools, that negatively influences on quality of human capital.

\section{References}

Barro, R. (1998). Human Capital and Growth in Gross Country Regressions'. Harvard University.

Becker, G. S. (1993). Human Capital. A Theoretical and Empirical Analysis, with Special Reference to Education. The University of Chicago Press. Chicago. London.

Bossel, H. (1999). Indicators for Sustainable Development: Theory, Method, Applications. A Report to the Balaton Group. Manitoba. International Institute for Sustainable Development.

Brown, L. R., \&. Kane, H. (1994). Full House: Reassessing the Earth's Population Carrying Capacity. W.W. Norton, New York.

Bruntland, G. (ed) (1987). Our Common Future: The World Commission on Environment and Development. Oxford. Oxford University Press.

Centrālās statistikas pārvaldes datu bāzes (2012). http://data.csb.gov.lv/

Colantonio, A. (2007). Social sustainability: An exploratory analysis of its definition, assessment methods metrics and tools. EIBURS Working Paper Series, 2007/01. Oxford Brooks University, Oxford Institute for Sustainable Development (CISD) - International Laud Markets Group, Oxford.

Eurostat http://epp.eurostat.ec.europa.eu/portal/page/portal/statistics/themes

Gurler, A. Z., Erdal, G., \& Erdal, H. (2006). The Effects of Agricultural Development on Ecosystem and the Sustainability of Development. Journal of Agronomy, 5: 293-298.

Hardi, P., Barg, S., Hodge, T., \& Pinter, L. (1997). Measuring Sustainable Development: Review of Current Practice. International Institute for Sustainable Development. Occasional Paper Number 17. Industry Canada. https://www.ic.gc.ca/eic/site/easaes.nsf/vwapj/op17e.pdf/\$file/op17e.pdf

Iedzīvotāju skaits (2011). VRAA.lv. http://www.vraa.gov.lv/uploads/documents/petnieciba/ petijumi/2012.05.22_iedzivotaju_skaits_reg_parskats.pdf

Ieslodzījuma vietu pārvaldes publiskais pārskats (2012). https://www.google.lv/url?url= https://www.tm.gov.lv/files/11_UHVibGlza2llIGdhZHUgcMSBcnNrYXRpLzIwMTIuZ 2Fkcy8yMDEyX2lldnAuZG9jeA/Publiskie\%2520gadu\%2520p\%25C4\%2581rskati/20 12.gads/2012_ievp.docx \&rct $=\mathrm{j} \& \mathrm{frm}=1 \& \mathrm{q}=\&$ esrc $=\mathrm{s} \& \mathrm{sa}=\mathrm{U} \& \mathrm{ved}=0 \mathrm{ahUKEwjqueuaqar}$ OAhVkD5oKHTa0AeIQFgglMAM\&usg=AFQjCNFFfYNA818vvyRocb0WZIIIw39_A

Indicators of Sustainable Development (1994). UN Department for Policy Coordination and Sustainable Development, December, 1994. 
Kizilaslan, N. (2007). An analytical approach to sustainable development in Turkey. Sustainable Development. Vjlume 15. Issue 4. 254-266.

Latvijas celš uz nekurieni. Tautsaimniecības blogs. http://www.makroekonomika.org/? page_id=90

Latvijas Republikas tiesību akti (2011). Likumi.lv http://likumi.lv/doc.php?id=191670

Meadows, D. L. (1995). It Is Too Late to Achieve Sustainable Development, Now Let Us Strive for Sustainable Development. Journal of Global Environment Engineering, 1, 114.

Murai, S. (1995a). Development of Global Ecoengineering using Remote Sensing and Geoinformation Systems. Toward Global Planning of Sustainable Use of the Earth: Development of Global Eco-engineering. (S.Murai ed.). Amsterdam. Elsevier. 1-11.

Murai, S. (1995b). Global environment and population carrying capacity. Population, land management, and environmental change. UNU Global Environmental Forum IV. (Edited by Juha I. Uitto and Akiko Ono). Tokyo, Japan, United Nations University, 1996. 77-83.

OECD (1998). Human Capital Investment: An International Comparison, Centre for International Research and Innovation

OECD (2001). The Well-being of Nations. The Rolle of Human and Social Capital.

Shultz, T. (1972). Human Capital: Policy Issues and Research Opportunities. Economic Research: Retrospect and Prospect, Volume 6. Human Resources. National Bureau of Economic Research. Cambridge. 1-84.

Šlaus, I., \& Jacobs, G. (2011). Human Capital and Sustainability.Sustainability 3 (1), 97-154; doi:10.3390/su3010097

Zemkopības ministrijas Tirgus un tiešā atbalsta departaments (2010). Lauksaimniecības nozaru attīstības tendences un prognozes. 2010. gada 5. martā) Riga. http://www.zm. gov.lv/doc_upl/Nozaru_tendences.pdf.

Тарасова, Н. П., \& Кручина, Е. Б. (2006). Индексы и индикаторы устойчивого развития. Материаль международной конференции «Устойчивое развитие: природа общество - человек». Том II. Москва. ЗАО Инновационный экологический фонд. 127-144.

Фролов, В., \& Агафонова, Е. (2011). Методические подходы к разработке показателей устойчивого развития сельских территорий. Экономическое возрождение России. №4 (30). 76-89. 